\title{
Clinical and histopathological features of orbital granular cell tumor: case report
}

\author{
Características clínicas e histopatológicas de tumor de células granulares da órbita: relato de caso
}

\author{
Bruno F. Fernandes ${ }^{1}$, Rubens Belfort Neto ${ }^{1,2}$, Alexandre Nakao Odashiro ${ }^{1,3}$, Patricia Rusa Pereira ${ }^{1,2}$, Miguel N. Burnier JR. ${ }^{1,2}$
}

\begin{abstract}
A 53 year-old woman presented with a slowly progressive, painless proptosis OS Computed tomography disclosed a round, homogeneous, well-delimited lesion in the inferior-temporal orbit. The tumor was composed of round cells with eosinophilic granular cytoplasm. Some of the cells had larger eosinophilic granules surrounded by a clear halo; known as pustulo-ovoid bodies of Milian or Bangle bodies. The diagnosis of a granular cell tumor was then established and confirmed by immunohistochemistry. Granular cell tumors are uncommon benign soft tissue neoplasms that have a predilection for the head and neck region. Awareness of the typical histopathological features is crucial for the correct diagnosis.
\end{abstract}

Keywords: Orbital neoplasms/diagnosis; Exophthalmos; Tomography, X-ray computed; Case report

\section{RESUMO}

Mulher de 53 anos apresentou proptose lentamente progressiva no olho esquerdo. Tomografia computadorizada mostrou uma lesão na região temporal inferior da órbita esquerda, bem delimitada, arredondada, homogênea. O tumor era composto de células com citoplasma granular eosinofilico. Algumas das células possuíam grandes grânulos eosinofilicos circundados porum halo claro, conhecidos como corposovoides-pustulares de Milian or corpos de Bangle. O diagnóstico de tumor de células granulares foi estabelecido, confirmado pela imuno-histoquímica. Tumor de células granulares são neoplasias incomuns com predileção da região da cabeça e pescoço. O conhecimento das características histopatológicas típicas são cruciais para o correto diagnóstico.

Descritores: Neoplasias orbitárias/diagnóstico; Exoftalmia;Tomografiacomputadorizada por raios x; Relato de caso

\section{INTRODUCTION}

Granular cell tumors (GCT) are uncommon benign soft tissue neoplasms that have a predilection for the head and neck region. Abrikossoff, in 1926, was the first to histopathologically describe it as a myoblastoma ${ }^{(1)}$. The combined input from immunohistochemistry and electron microscopy has clarified the morphology of this lesion, which is probably derived from a Schwann cell(2,3). GCTs are found in various locations, usually as a small, solitary, benign lesion. GCTs of the eye and ocular adnexae are rare, but have been described in the orbit, periorbital skin and eyelids, extraocular muscles, lacrimal sac, ciliary body, conjunctiva, and caruncle ${ }^{(4)}$.

\section{CASE REPORT}

A 53 year-old woman presented with a slowly progressive, painless proptosis OS. During clinical examination, an upward displacement of the left globe was seen, although the exam was otherwise unremarkable. Visual acuity was 20/20 in both eyes and intraocular pressure was $16 / 16 \mathrm{mmHg}$. Computed tomography disclosed a round, homogeneous, well-delimited lesion in the inferior-temporal orbit, indenting the globe without invading any orbital structure (Figure 1). An excisonal biopsy was performed and the surgery was uneventful.

The tumor was solid and entirely encapsulated. It was composed of round cells with eosinophilic granular cytoplasm. Some of the cells had larger eosinophilic granules surrounded by a clear halo; known as pustulo-ovoid bodies of Milian or Bangle bodies. No mitosis or areas of necrosis were seen. Immunohistochemistry was performed and the tumor was positive for vimentin, S-100, NSE and CD 68 while SMA, actin, desmin, EMA, cytokeratins, chromogranin, and HMB45 were negative. The diagnosis of an orbital granular cell tumor was then established (Figure 2).

\section{DISCUSSION}

Although there are no unique clinical or radiological features distinct from other benign orbital tumors, GCT is easily recognized by routine light microscopy. The diastase-resistant, PAS-positive cytoplasmic granularity is typical of GCT. The granules are believed to be lysosomes or a component of the Golgi apparatus. In some cells, the granules aggregate to form the pustulo-ovoid bodies of Milian. A small number of cases can be less differentiated and, in those, immunohistochemistry in a valuable tool. GCTs are usually positive for vimentin, S-100 protein, NSE, CD 57 and CD 68, while negative for SMA, actin, desmin, EMA, cytokeratins, chromogranin and HMB 45.

Some GCTs may present atypical features and are further termed Malignant GCT. The distinction is done on histopathological grounds and the features are: Necrosis, nuclei spindling, vesicular nuclei with large nucleoli, increased mitotic activity (>2 mitoses/10 HPF at 200x), high nuclear to cytoplasmic ratio and nuclear pleomorphism. The presence of 3 or more of these features correlates with rates of local recurrences and metastasis of $32 \%$ and $50 \%$, respectively ${ }^{(5)}$.

Submitted for publication: March 24, 2011

Accepted for publication: October 5, 2011

Study was carried out at Henry C. Witelson Ocular Pathology Laboratory, McGill University, Montreal Canada.

${ }^{1}$ Physician, Department of Ophthalmology and Pathology. Henry C. Witelson Ocular Pathology Laboratory \& McGill University Health Centre. Montreal, QC, Canada.

Physician, Department of Ophthalmology, Universidade Federal de São Paulo - UNIFESP - São Paulo (SP), Brazil.

Physician, Department of Pathology, Universidade Federal de Mato Grosso do Sul - UFMS, Campo

Grande (MS), Brazil.

Funding: No specific financial support was available for this study

Disclosure of potential conflicts of interest: B.F.Fernandes, Employment at McGill University, Montreal, Canada; R.Belfort Neto, None; A.N.Odashiro, None; P.R.Pereira, None; M.N.Burnier Jr. Employment at McGill University, Montreal, Canada.

Correspondence address: Alexandre Nakao Odashiro. 3775 University Street, room 216, Montreal, Quebec - Canada. H3A-2B4 - Email: alexandrenakao@yahoo.com.br 

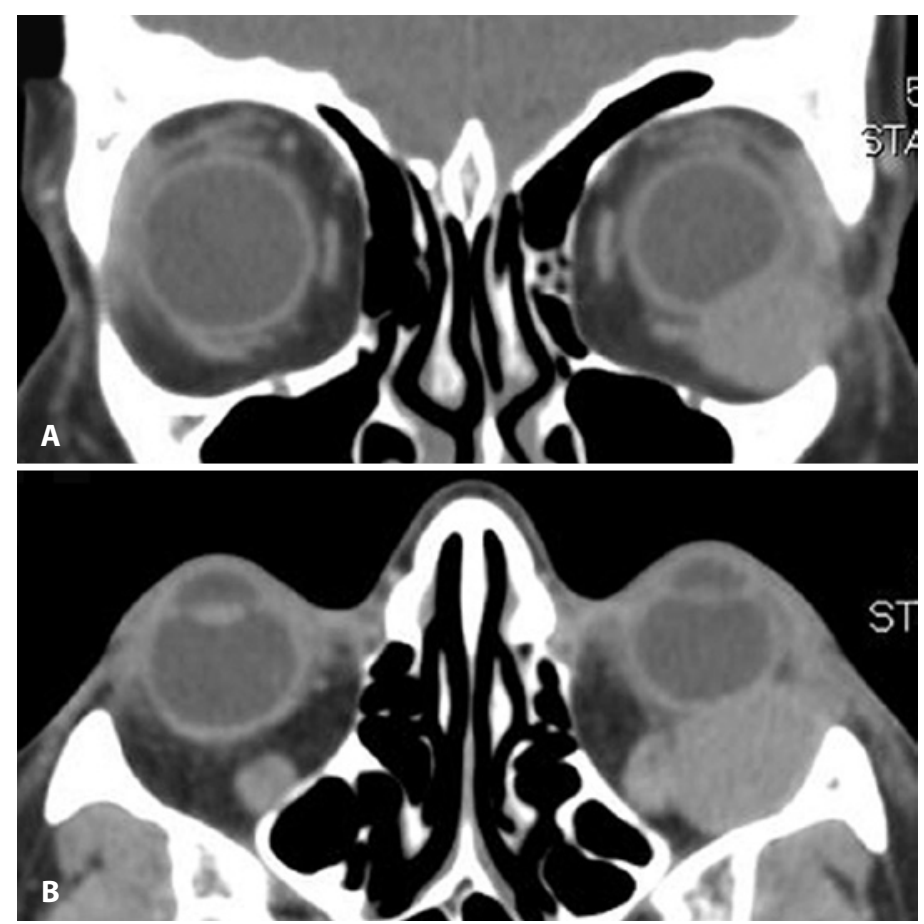

Figure 1.Coronal (A) and axial (B) computed tomography showing a well-defined lesion in the inferior temporal orbit, indenting the globe but without compromising any orbital structure.

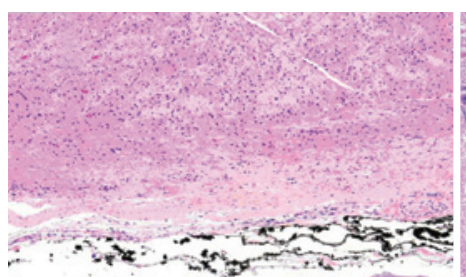

A
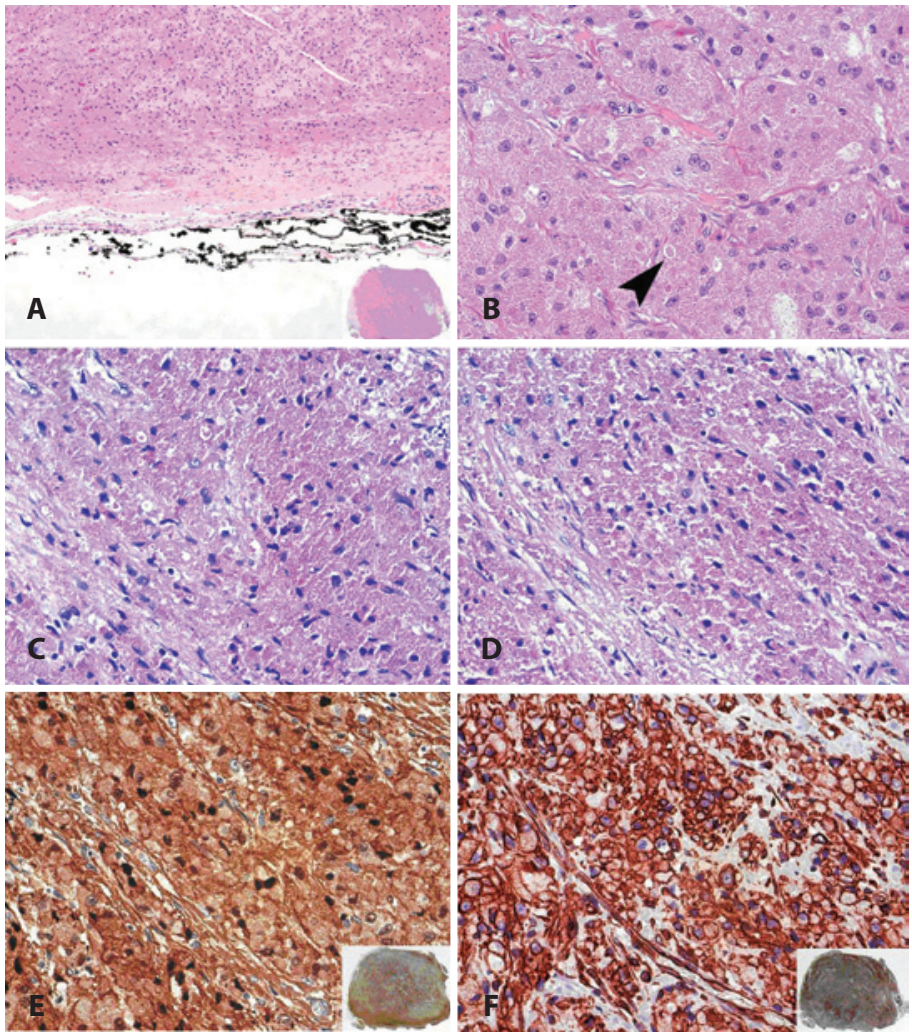

Figure 2. A) The tumor was solid (inset) and encapsulated (H\&E, X200). B) The cells had a granular eosinophlic cytoplasm and presented the characteristic pustulo-ovoid bodies of Milian (arrowhead) (H\&E, X400). C) The intra-citoplasmatic granules were PAS-positive (PAS, X400). D) The granules remained positive after treatment with diastase (PAS + Diastase, X400). E) Strong and diffuse (inset) immunostaining for S-100 (X400). F) Vimentin was also strong and diffusely (inset) positive (X400). 
In summary, we presented histopathological and immunohistochemical findings of a rare orbital tumor. Awareness of the typical histopathological features is crucial for the correct diagnosis. Moreover, the criteria of malignancy must be well know in order to proper counseling and determining the prognosis of each patient.

\section{ACKNOWLEDGEMENTS}

We would like to acknowledge Dr François Codère for surgical management as well as the clinical images, and Dr Enzo Castiglione and Dr. Maria E. Orellana for the management with the surgical specimen.

\section{REFERENCES}

1. Abrikossoff A. Über Myome, ausgehend von der quergestreiften willkürlichen Muskulatur. Virchows Arch Pathol Anat. 1926;260:215-33.

2. Chimelli L, Symon L, Scaravilli F. Granular cell tumor of the fifth cranial nerve: further evidence for Schwann cell origin. J Neuropathol Exp Neurol. 1984;43(6):634-42.

3. Fisher ER, Wechsler H. Granular cell myoblastoma--a misnomer. Electron microscopic and histochemical evidence concerning its Schwann cell derivation and nature (granular cell schwannoma). Cancer. 1962;15:936-54.

4. Jaeger MJ, Green WR, Miller NR, Harris GJ. Granular cell tumor of the orbit and ocular adnexae. Surv Ophthalmol. 1987;31(6):417-23.

5. Fanburg-Smith JC, Meis-Kindblom JM, Fante R, Kindblom LG. Malignant granular cell tumor of soft tissue: diagnostic criteria and clinicopathologic correlation. Am J Surg Pathol. 1998;22(7):779-94. Erratum in: Am J Surg Pathol 1999;23(1):136.

\title{
VI Congreso Latinoamericano de Glaucoma
}

\author{
05 a 06 de outubro de 2012 \\ Santiago - Chile
}

Informações: E-mail: dgrigera2@fibertel.com.ar 